\title{
Peran Pelembab dalam Mengatasi Kondisi Kulit Kering
}

\author{
Maria Elvina Tresia Butarbutar*, Anis Yohana Chaerunisaa
}

Departemen Farmasetika dan Teknologi Formulasi, Fakultas Farmasi, Universitas Padjadjaran, Jalan

Raya Bandung Sumedang KM 21 Jatinangor, Jatinangor 45363,

Jawa Barat, Indonesia

*E-mail: maria18015@mail.unpad.ac.id

(Submit 21/7/2020, Revisi 10/8/2020, Diterima 21/8/2020, Terbit 29/10/2020)

\begin{abstract}
Abstrak
Kondisi kulit kering merupakan salah satu masalah kulit yang dapat dialami oleh semua orang. Kondisi kulit kering bagi sebagian orang dapat menimbulkan rasa tidak nyaman bahkan dapat menyebabkan terjadinya penyakit, seperti dermatitis atopik yang merupakan salah satu penyakit akibat adanya peradangan pada kulit. Banyak faktor yang menyebabkan terjadinya kulit kering, diantaranya iklim, genetik, dan lingkungan. Salah satu, solusi untuk mengatasi kondisi kulit kering adalah penggunaan produk pelembab. Pelembab merupakan salah satu produk komersial yang banyak tersedia di pasaran. Formulasi pelembab dapat bersifat sebagai humektan, oklusif, dan emolien. Masing-masing memiliki mekanisme kerja dan bahan yang berbeda. Berdasarkan hal tersebut perlu adanya suatu kajian mengenai perkembangan pelembab, mekanisme dari setiap sifat pelembab, dan bahan-bahan yang dapat berfungsi sebagai pelembab.
\end{abstract}

Kata kunci: Kulit kering, pelembab, humektan, oklusif, emolien.

\section{Pendahuluan}

Kulit merupakan bagian terbesar pada tubuh manusia yang terletak di bagian terluar atau permukaan tubuh yang berinteraksi langsung dengan lingkungan. Dalam kehidupan sehari-hari, kulit terus-menerus berinteraksi dengan berbagai produk atau bahan asing, seperti kosmetik, benda-benda sekitar, dan kondisi lingkungan. Pengaruh setiap produk memberikan interaksi yang berbeda pada setiap kulit individu. ${ }^{1}$

Salah satu produk yang umumnya berinteraksi dengan kulit adalah kosmetik. Sebagian besar penggunaan kosmetik adalah untuk mengatasi permasalah kulit, seperti kondisi kulit kering walaupun ada sebagian individu yang memiliki jenis kulit kering pada bagian tubuh tertentu. Kulit kering dapat dipengaruhi oleh beberapa faktor, diantaranya kulit mengalami dehidrasi, kemampuan sebum, kekasaran permukaan kulit, dan hidrofilitas. ${ }^{2}$ Selain itu, kulit kering juga dipengaruhi oleh iklim, usia, dan pemakaian produk yang tidak sesuai jenis kulit. ${ }^{1}$ Diantara beberapa faktor yang telah disebutkan terjadinya dehidrasi kulit adalah faktor yang paling dominan. ${ }^{2}$ 
Secara alami, kulit memiliki lapisan lemak tipis pada permukaannya yang terdiri atas produksi kelenjar minyak yang berfungsi untuk melindungi kulit dari kelebihan penguapan air yang akan menyebabkan dehidrasi kulit. Saat ini, banyak penelitian mengenai kosmetik dengan tujuan menciptakan suatu produk yang inovatif untuk mengatasi permasalahan individu dengan kondisi kulit kering. Salah satu solusi yang ditawarkan untuk mengatasi jenis kulit kering, yaitu penggunaan kosmetik pelembab (moisturizer). Pelembab merupakan produk yang ditujukan untuk meningkatkan hidrasi kulit. $^{3}$ Saat ini, banyak produk komersil pelembab yang ditawarkan, namun perlu diperhatikan pemilihan pelembab bergantung pada kebutuhan dan kecocokan pada setiap individu.

Jenis bahan pelembab dapat dikategorikan dalam beberapa kelompok, yaitu pelembab yang bersifat oklusif, humektan, dan lipid interseluler pada stratum corneum (SC). Bahan yang bersifat oklusif dan humektan adalah bahan yang paling banyak diformulasikan dalam komponen produk pelembab karena memiliki campuran lemak yang dapat mengembalikan kelembaban kulit. Sedangkan, pelembab yang bersifat lipid interseluler pada SC biasanya digunakan untuk produk pelembab yang mengatasi infeksi kulit. $^{3}$

Mekanisme pelembab menghidrasi kulit adalah dengan mengurangi transepideral water loss (TEWL) dan menarik air untuk menghidrasi SC dan epidermis. Beberapa bahan yang dapat mengurangi terjadinya TEWL yang bersifat oklusif, diantaranya petroleum, paraffin, dimethicone, cyclo-methicone, dan minyak mineral. Bahan yang bersifat humektan dan dapat menarik air ke kulit, diantaranya gliserin, sorbitol, propilen glikol, hyaluronic acid, sodium, dan protein. ${ }^{4}$ Bahan yang bersifat lipid interseluler pada SC, yaitu asam lemak (asam linoleat, asam stearat, dan asam palmitat), kolestrol, dan ceramides. Golongan asam lemak adalah bahan yang banyak digunakan pada produk pelembab yang bersifat lipid interseluler. ${ }^{5}$ Ditinjau begitu besar peran pelembab untuk mengatasi kondisi kulit kering, maka artikel review ini akan mengkaji mengenai perkembangan pelembab, tipe pelembab, mekanisme pelembab, formulasi pelembab, dan bahan alam yang berpotensi sebagai pelembab.

\section{Metode}

Metode yang digunakan dalam artikel review ini berdasarkan jurnal internasional yang bersumber dari database Google schoolar dan Sciendirect tahun 2000 - 2019 dengan kata kunci "dry skin" dan "moisturizer" dan "humectant" dan "emollient" dan "occlusive".

\section{Hasil dan Pembahasan}

\section{Karakteristik Kulit Kering}

Kulit kering dapat dialami oleh siapa saja. Kulit kering masih menjadi permasalahan bagi sebagian besar individu. Ciri-ciri kulit kering, diantaranya terlihat kering, terlihat kusam, kulit lebih sensitif, bersisik, lekas berkerut, dan pori-pori terlihat halus. Faktor yang mempengaruhi terjadinya kulit kering, yaitu faktor genetik, faktor lingkungan, kondisi struktur kulit, penyakit kulit, pola makan, dan pengaruh obat-obatan. 
Permasalahan kulit kering disebabkan oleh adanya interkasi yang kompleks. ${ }^{6}$ Kesan kering terjadi oleh adanya sensor yang melekat pada komponen di kulit, bersama dengan adanya perubahan yang terlihat pada permukaan kulit. ${ }^{7}$ Faktor-faktor yang turut berkonstribusi terhadap terjadinya kulit kering dan eksim dapat dilihat pada Tabel 1 dan karakteristik kulit kering dapat dilihat pada Tabel 2.

Tabel 1. Faktor yang berkonstribusi terhadap terjadinya kulit kering dan eksim. ${ }^{6}$

Suhu lingkungan dan kelembaban yang rendah

Paparan bahan kimia dan mikroorganisme

Penuaan dan stres psikologis

Eksim atopik

Psoriasis

Ichthyosis

Tabel 2. Karakteristik kulit kering. ${ }^{6}$

\begin{tabular}{|c|c|}
\hline Metode & Hasil \\
\hline Visual & $\begin{array}{l}\text { Kemerahan, permukaan yang kasar, terdapat } \\
\text { bercak putih, dan bersisik }\end{array}$ \\
\hline Sensorik & $\begin{array}{l}\text { Terasa kering, menimbulkan rasa sakit, tidak } \\
\text { nyaman, dan gatal }\end{array}$ \\
\hline Sensasi & Kasar dan tidak rata \\
\hline Kimia & $\begin{array}{l}\text { Mengurangi kadar air dan kelembaban alami, } \\
\text { komposisi lipid berubah }\end{array}$ \\
\hline Fungsional & $\begin{array}{l}\text { Peningkatan permeabilitas, yaitu tingkat } \\
\text { transepidermal terjadi kehilangan air yang lebih } \\
\text { tinggi dan kurang resistesi terhadap } \\
\text { penyerapan zat berbahaya }\end{array}$ \\
\hline
\end{tabular}

\section{Faktor Rasial Terhadap Sifat Kulit}

Meskipun kulit kering dapat ditemukan pada setiap ras namun tingkat keparahan xerosis dapat sangat bervariasi. Pengaruh ras terhadap sifat kulit dapat dilihat pada Tabel 3. Beberapa dekade terakhir, telah dilakukan penelitian mengenai kelompok berdasarkan ras dengan perbedaan mendasar pada struktur kulit dan fungsinya. Perbedaan yang sangat jelas, yaitu dalam warna kulit sekunder terhadap keberadaan melanin. yang terkait dengan paparan sinar matahari. 8,9

Beberapa penelitian juga menggambarkan pengaruh pigmentasi kulit karena faktor perubahan usia. ${ }^{8}$ Perbedaan ras terhadap sifat kulit mungkin secara signifikan mempengaruhi kemampuan kulit untuk mempertahankan kelembaban. ${ }^{10}$ Telah banyak investigasi terbaru dengan pengukuran objektif untuk melaporkan pengaruh ras terhadap perbedaan sifat kulit dengan akurat. ${ }^{11}$ Dapat dilihat pada Tabel 3. 
Tabel 3. Perbedaan sifat kulit berdasarkan ras. ${ }^{11}$

\begin{tabular}{|l|c|c|c|c|} 
& Transepidermal & Kandungan Air & Level ceramide & $\begin{array}{c}\text { Reaktivitas } \\
\text { Kulit }\end{array}$ \\
\hline Kulit hitam & ++ & + & + & + \\
\hline Kulit Kaukasian & + & ++ & ++ & ++ \\
\hline Kulit Asia & +++ & +++ & +++ & +++ \\
\hline
\end{tabular}

Keterangan: + (rendah); ++ (sedang); +++ (tinggi)

\section{Mekanisme Xerosis}

Kulit normal mengandung kadar histamin dan sitokin yang lebih rendah dibandingkan dengan kulit kering. Pelindung yang berada di sekitar corneosit turut terlibat dalam patologi kulit kering. Selain itu, kulit kering telah terbukti mengandung kadar keratin 5 dan 14 yang lebih tinggi. Gambar di sebelah kanan menunjukkan SC yang retak yang merupakan salah satu karakteristik kulit kering dan berhubungan dengan penurunan kadar air (pola biru) dan terjadinya peningkatan ikatan silang involucrin (silang kuning). ${ }^{11}$

Kulit Normal

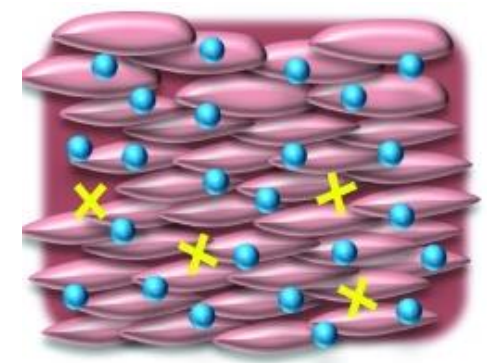

Kulit Normal

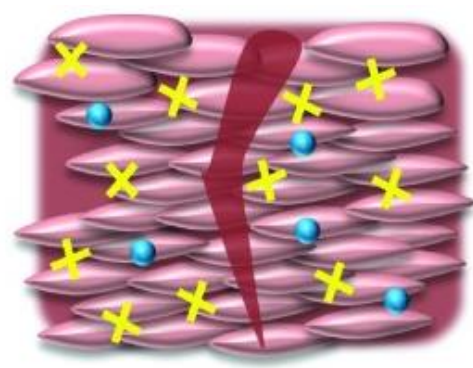

Gambar 1. Mekanisme Xerosis (Kulit Normal: Mengurangi histamin, mengurangi sitokin inflamasi, ekspresi involucrin yang normal. Kulit Kering: Peningkatan histamin, peningkatan sitokin inflamasi, ekspresi prematur pada involucrin). ${ }^{11}$

\section{Mekanisme Pengaturan Hidrasi Kulit}

Terdapat keseimbangan antara keluar dan masuknya cairan di SC. Masuknya cairan endogen berasal dari proses difusi dari dermis ke permukaan kulit dan juga sekresi kelenjar keringat. Pemasukan secara eksogen meningkat ketika kelembaban relatif tinggi. Keseimbangan terjadi bila kelembaban relatif lingkungan, yaitu $85 \%$, di bawah konsentrasi tersebut terjadi kehilangan air transepidermal TEWL dan di atas konsentrasi tersebut terjadi sebaliknya. ${ }^{12}$

Kehilangan cairan juga dihubungkan dengan berbagai keadaan, misalnya cuaca berangin, suhu lingkungan yang tinggi maupun rendah, udara yang kering, penggunaan bahan yang mengandung surfaktan, bahan alkali (sabun), pelarut organik, diantaranya eter, aseton, alkohol, enzim proteolitik dan lipolitik, proses penuaan, serta berbagai kelainan kulit. ${ }^{12}$ 
Jacobi menyatakan bahwa kemampuan kulit untuk menyimpan kelembaban berhubungan dengan adanya bahan yang larut dalam air, dinamakan faktor $\mathrm{X}$ atau faktor pelembab alami natural moisturizing factor (NMF). Kelembaban bergantung pada 3 faktor, yaitu kecepatan cairan mencapai SC, kecepatan penguapan cairan, kemampuan stratum korneum untuk menahan cairan bergantung kepada integritas lapisan hidrolipid, adanya NMF, cukup tersedianya air interseluler, integritas membran sel dan semen interseluler yang berasal dari lipid penunjang. ${ }^{12}$

Lapisan hidrolipid terdiri atas air, ion, asam amino, urea, skualen, trigliserida, kolesterol bebas dan esternya, serta asam lemak. Lapisan hidrolipid berasal dari sebum dan sekresi keringat. SC terdiri dari 58\% keratin, 30\% NMF, dan 11\% lipid. NMF terdiri dari asam amino bebas, asam urokanan, asam pirilidon karbosiklat, urea, elektrolit, garam, dan fraksi gula yang indeterminan. Komposisi semen interseluler terdiri atas fingo lipid $49 \%$, asam lemak $26 \%$ (asam linoleat), dan kolesterol $20 \%{ }^{12}$

\section{Kosmetika Pelembab}

Perawatan kulit dapat dilakukan dengan menggunakan beberapa produk, seperti salep, krim, losion, minyak, dan gel. Salah satu produk kosmetik yang banyak digunakan adalah kosmetik pelembab. Istilah pelembab atau dikenal dengan sebutan emolien adalah penambahan air ke dalam kulit dan meningkatkan kapasitas pengikatan air pada SC. ${ }^{13}$ Lapisan SC adalah struktur yang interaktif dan dinamis, fungsinya sebagai pelindung dan menjaga kelembaban kulit.

Pelembab telah dirancang untuk memberikan kelembaban atau mengembalikan kelembaban pada SC. ${ }^{14}$ Pelembab menjadi salah satu produk yang banyak diminati oleh konsumen, bahkan sekarang produk pelembab telah dikembangkan menggunakan bahan alami, seperti dari tumbuhan dan vitamin. ${ }^{15}$ Dalam buku International Cosmetic Ingredient Dictionary telah tercatat 125 zat yang berfungsi sebagai emolien dan hampir 200 zat bersifat higroskopis yang digunakan untuk meningkatkan kadar air dalam kulit. ${ }^{16}$

Pelembab umumnya digunakan untuk mengurangi garis-garis halus, menghaluskan, dan melembabkan kulit. Ini mungkin dapat meningkatkan kepercayaan diri seorang inividu, kepuasan psikologis, dan kualitas hidup. ${ }^{3}$ Pelembab bekerja efektif untuk mengatasi kulit kering dan menjaga kahalusan kulit. ${ }^{17}$

Pelembab juga memiliki beberapa manfaat selain untuk melembabkan kulit. Beberapa fungsi lainnya, yaitu sebagai berikut:

1. Anti-inflamasi

Beberapa komponen pelembab, seperti glycyrrhetinic acid, palmitoyl-ethanolamine, telmesteine, vitis vinifera, dan ceramides yang berpotensi sebagai anti-inflamasi yang cukup besar melalui berbagai mekanisme, diantaranya memblokir aktivitas siklooksigenase, mengatur sitokin, memproduksi prostanoid proinflamasi, serta menyediakan efek yang menenangkan pada kulit yang sedang meradang, seperti pada dermatitis atopik. ${ }^{18}$ 
2. Antipruritik

Pelembab dengan basis air dapat memberikan efek dingin pada kulit. Pelembab ini biasanya mengadung bahan seperti mentol sebagai zat aditifnya yang dapat memberikan sensasi dingin dan dapat mengurangi rasa gatal. ${ }^{18}$

3. Antimitotik

Pelembab ini berupa minyak mineral yang memiliki sifat antimomotik epidermal dengan derajat rendah dan dapat membawa efek terapetik pada penyakit kulit dengan meningkatkan aktivitas mitosis epidermal, seperti psoriasis. ${ }^{18}$

4. Penyembuhan Luka

Hyaluronic acid telah menujukkan efektivitas dapat mempercepat penyembuhan luka. ${ }^{19}$

\section{Tipe Pelembab}

Komponen pelembab dapat dikelompokkan ke dalam beberapa kategori, yaitu humektan, oklusif, emolien, dan konstituen pelembab alami atau esensial protein. Tipe pelembab dan contohnya seperti yang disajikan pada Tabel 4 .

Humektan adalah zat yang dapat menarik air jika dioleskan pada kulit. Secara teoritis dapat meningkatkan hidrasi SC. Bahan humektan yang umumnya digunakan termasuk gliserin, sorbitol, urea, asam alfa hidroksi, dan glukosa. ${ }^{20}$ Selain itu, sifat higroskopis dimiliki oleh beberapa humektan, diantaranya asam alfa hidroksi, amonium laktat juga terbukti mengurangi terjadinya penebalan abnormal pada SC, meningkatkan kohesi antara corneocytes, mengurangi penampilan yang terlihat pada ichthyosis, dan kondisi hiperkarotik lainnya. Perlu diingat, penggunaan humektan terjadi secara transepidermal bukan berasal dari lingkungan. Karena itu, penguapan terus terjadi dari kulit yang dapat memperburuk kondisi kulit dan menyebabkan kulit menjadi kasar. Konsentrasi yang tinggi pada beberapa humektan, diantaranya urea, gliserin, dan propilen glikol dapat menjadi penyebab terjadinya iritasi dan harus dihindari pada individu yang memiliki kulit sensitif. ${ }^{21}$

Oklusif secara fisik dapat memblokir secara transepidermal terjadinya kehilangan air pada SC dan membantu mempertahankan kadar air. ${ }^{20}$ Lanolin adalah salah satu zat digunakan sebagai oklusif dan telah lama digunakan sebagai pelembab tunggal. Oklusif terdiri dari berbagai campuran, seperti ester, diester, hidroksi ester yang memiliki berat molekul yang tinggi, lanolin alkohol, dan asam Ianolin. Namun sampai saat ini lanolin bisa dikatakan cukup efektif untuk meminimalkan terjadinya penguapan dan juga dermatitis. Oleh sebab itu, penggunaan lanolin harus dibatasi pada individu yang memiliki jenis kulit yang sensitif. Selain lanolin, petrolatum juga telah banyak digunakan sebagai pelembab. Seiring meningkatnya permasalah kesehatan dan juga lingkungan, saat ini telah dikembangkan derivat petroleum dari minyak bumi yang menjadi alternatif. Bahan tersebut, diantaranya dimeticon dan zinc dioxide. Beberapa oklusif diantaranya juga memiliki efek emolien yang lebih kemampuannya untuk meningkatkan kemampuan kualitas kulit secara keseluruhan. ${ }^{11}$ 
Tabel 4. Tipe pelembab dan contohnya. ${ }^{11}$

\begin{tabular}{|c|c|c|}
\hline Kelompok & Mekanisme Aksi & Contoh \\
\hline Humektan & Menarik air ke SC & $\begin{array}{l}\text { Gliserin } \\
\text { Sorbitol } \\
\text { Urea } \\
\text { Asam alpa hidroksi } \\
\text { Gula }\end{array}$ \\
\hline Oklusif & $\begin{array}{l}\text { Pelindung dan mencegah } \\
\text { kehilangan kandungan air }\end{array}$ & $\begin{array}{l}\text { Lanolin } \\
\text { Petrolatum } \\
\text { Minyak mineral } \\
\text { Silikon } \\
\text { Zinc oxide }\end{array}$ \\
\hline Emolien & $\begin{array}{l}\text { Mengisi ruang di antara } \\
\text { corneocyte }\end{array}$ & $\begin{array}{l}\text { Squalene } \\
\text { Kolestrol } \\
\text { Asam lemak } \\
\text { Asam hialuronik }\end{array}$ \\
\hline $\begin{array}{l}\text { Pelembab } \\
\text { alami/esensial } \\
\text { protein }\end{array}$ & $\begin{array}{l}\text { Kombinasi rendah dari berat } \\
\text { molekul zat yang tahan air }\end{array}$ & $\begin{array}{l}\text { Asam Amino } \\
\text { Amonia } \\
\text { Uric acid } \\
\text { Glucosamine } \\
\text { Creatinine } \\
\text { Citrate } \\
\text { Organic acids } \\
\text { Peptides }\end{array}$ \\
\hline $\begin{array}{l}\text { Nonsteroidal anti- } \\
\text { inflamasi }\end{array}$ & $\begin{array}{l}\text { Sebanding dengan steroid } \\
\text { yang berada pada kulit yang } \\
\text { berfungsi memperbaiki } \\
\text { fungsi SC }\end{array}$ & $\begin{array}{l}\text { MimyX Cream } \\
\text { Atopiclair }^{\circledR} \\
\text { EpiCeram }^{\circledR}\end{array}$ \\
\hline
\end{tabular}

Emolien sering digunakan ke dalam produk pelembab yang berfungsi untuk menghaluskan kulit melalui pengisian ruang antara lapisan corneocyt. Meskipun tidak seperti sifat bahan oklusif, emolien juga dapat berfungsi mencegah terjadinya penguapan air pada kulit. Umumnya emolien terdiri dari emulsi air dalam minyak dengan komponen minyak sebesar $3-25 \% .{ }^{22}$

Konsentrasi minyak dapat mempengaruhi dan mempermudah penyebaran produk saat diaplikasikan. Bahan emolien yang umumnya digunakan dalam suatu produk, termasuk squelene, kolestrol, dan asam lemak. Squelene adalah bahan organik alami yang berasal dari minyak hati ikan hiu, biji bayam, gandum, dan zaitun. ${ }^{23}$ Secara komersial, squelen biasanya terhidrogenasi untuk menghasilkan turunan yang jenuh yang dikenal dengan sebutan squalene, yang tidak rentan terhadap oksidasi. ${ }^{24}$ Pada konsentrasi yang digunakan dalam produk pelembab, baik squalene dan turunan squalene telah terbukti dapat menyebabkan iritasi. ${ }^{25}$ Selain itu, sintesis ceramide juga telah tersedia secara komersial dan terbukti efektif dalam memperbaiki kulit yang kering. ${ }^{26}$ Untuk individu yang memiliki kulit yang lebih berminyak produk bebas minyak telah dikembangkan dengan menggunakan propilen glikol atau gliserin. ${ }^{11}$ 
Natural Moisturizing Factor (NMF) menggambarkan senyawa yang ditemukan pada epidermis dimana dapat mengurangi dehidrasi kulit. ${ }^{27}$ NMF mengandung kombinasi beberapa jenis bahan alami, seperti asam amino bebas, asam urokanik, garam anorganik, gula, asam laktat, dan urea. ${ }^{28}$ Banyak diantaranya memiliki efisiensi yang sangat tinggi dalam menarik dan mengikat air dari lingkungan yang memungkinkan terjadinya hidrasi corneocyt yang memadai bahkan pada lingkungan dengan kelembaban yang rendah. Sebagian besar NMF berasal dari pemecahan filaggrin yang kaya akan histidin dan merupakan protein dengan molekul yang besar dalam lapisan corneocyt yang membantu pembentukan filamen pada keratin. Kulit yang sering dibersihkan dapat mengurangi tingkat NMF.11

Kelompok pelembab anti-inflamasi, senyawa yang telah disetujui FDA. Contoh produk produk dalam pelembab ini adalah krim MimyX, Atopiclair ${ }^{\circledR}$, EpiCeram ${ }^{\circledR}$. Produk pelembab tersebut adalah produk yang dirancang untuk kulit kering dan penyakit dermatitis atopik. Krim MimyX mengandung palmitoylethanolamide, yaitu suatu lemak bioaktif yang ditujukan untuk pasien yang mengalami dermatitis atopik. Atopiclair ${ }^{\circledR}$ tidak mengandung bahan aktif medis, namun berfungsi sebagai krim hidrofilik yang terdiri atas hyaluronic, telmesteine, dan glycyrrhetinic. ${ }^{26}$ EpiCeram $^{\circledR}$ adalah krim yang mengandung ceramide, asam lemak bebas, dan kolestrol. Ketiga krim ini adalah produk pelembab yang telah menunjukkan kemampuan mengatasi dermatitis atopik. ${ }^{11}$

\section{Mekanisme Kerja Pelembab}

Kulit berfungsi sebagai penghalang dan pelindung jaringan dari infeksi, stres mekanik, dan iritasi yang disebabkan oleh bahan kimia. Jika fungsi kulit rusak maka dapat menyebabkan peningkatan TEWL. ${ }^{29}$

Air yang berada pada lapisan epidermis bergerak naik ke atas untuk menghidrasi sel SC yang kemudian hilang karena terjadinya penguapan. Kadar air pada epidermal sangat penting untuk mencegah terjadinya kekeringan kulit dan mempertahankan plastisitas kulit. ${ }^{8}$ SC merupakan membran aktif yang digambarkan seperti batu bata dimana hilangnya lipid antar sel akan membentuk seperti bilayer, misalkan ceramide, kolestrol, dan asam lemak. Hilangnya lipid antar sel akan menyebabkan kerusakan pembentukan pelindung kulit dan menyebabkan kulit menjadi kering. ${ }^{6}$

Pelembab dapat meningkatkan perbaikan SC, menjaga integritas, dan penampilan kulit yang bertindak sebagai pelembab, emolien, dan oklusif, bergantung dengan mekanisme kerjanya masing-masing. ${ }^{30}$ Pelembab meningkatkan hidrasi kulit dan meningkatkan kadar air pada SC dengan cara menyediakan air ke kulit dan meningkatkan oklusi untuk mengurangi TEWL. Hal itu juga mencakup celah kulit dan memberikan lapisan film pelindung yang menenangkan dan melindungi kulit dari gesekan. Selanjutnya, aplikasi pelembab dapat menghaluskan permukaan kulit dengan mengisi ruang-ruang di antara sebagian deskuamasi kulit yang mengelupas. Pelembab juga dapat mengembalikan kemampuan lapisan ganda lipid antar sel untuk menyerap, mempertahankan dan mendistribusikan air. 
Mekanika kulit menjadi berubah setelah mengalami hidrasi dan mencegah degradasi corneo desmosome, mencegah akumulasi corneocyte. Loden, menyimpulkan bahwa produk perawatan kulit tidak hanya berfungsi pada permukaan saja, tetapi juga dapat menembus kulit untuk mempengaruhi struktur dan fungsi kulit tersebut. ${ }^{31}$

\section{Formula Pelembab}

Sebagian besar pelembab ada yang menggabungkan emolien, oklusif, dan humektan. Kombinasi oklusif dan humektan dapat meningkatkan kapasitas air dalam kulit. Penambahan emolien tertentu dapat meningkatkan kualitas estetika dan stabilitas bahan aktif pada produk pelembab. Ketika gliserol dikombinasikan dengan oklusif, maka kekeringan kulit akan secara sinergis berkurang. ${ }^{31}$ Formulasi utama berupa sistem emulsi dan kebanyakan dalam bentuk losion dan krim. Berbagai macam formulasi pelembab disajikan pada Tabel 5 .

Tabel 5. Formulasi berbagai macam pelembab. ${ }^{17}$

\begin{tabular}{|c|c|c|c|c|}
\hline Klasiffkasi & Losion & Krim & Oinmen & Gel \\
\hline Fase & $\begin{array}{l}\text { Minyak } \\
\text { dalam air }\end{array}$ & $\begin{array}{l}\text { Air dalam minyak atau } \\
\text { minyak dalam air }\end{array}$ & $\begin{array}{l}\text { Air dalam minyak atau } \\
\text { minyak dalam air }\end{array}$ & Hidrofobik atau hidrofilik \\
\hline Komposisi & $\begin{array}{l}\text { Minyak, air, } \\
\text { propilen } \\
\text { glikol }\end{array}$ & $\begin{array}{l}\text { W/O: pengemulsi seperti } \\
\text { monogliserida, ester } \\
\text { sorbitan dan lemak wol } \\
\text { O/W: zat pengemulsi } \\
\text { seperti sabun natrium } \\
\text { atau trietanolamin, } \\
\text { alkohol lemak tersulfat } \\
\text { dan polisorbat. Bila perlu } \\
\text { dapat dikombinasikan } \\
\text { dengan zat pengemulsi } \\
\text { W/O }\end{array}$ & $\begin{array}{l}\text { W/O: hidrokarbon yang } \\
\text { tidak larut dalam air } \\
\text { seperti parafin, minyak } \\
\text { sayur, lemak hewani, } \\
\text { lilin, gliserida sintetik } \\
\text { dan polyalkysiloxanes } \\
\text { O/W: campuran glikol } \\
\text { polietilen cair dan padat. }\end{array}$ & $\begin{array}{l}\text { Gel hidrofobik (oleogel): } \\
\text { Parafin cair dengan polietilen } \\
\text { atau minyak lemak gel dengan } \\
\text { silika koloid, alumunium, atau } \\
\text { sabun seng } \\
\text { Gel hidrofilik (hidrogel): air, } \\
\text { gliserol atau propilen glikol } \\
\text { yang di gel dengan zat yang } \\
\text { sesuai seperti tragakan, pati, } \\
\text { turunan dari selulosa, polimer } \\
\text { vinil karboksi dan magnesium. }\end{array}$ \\
\hline Karakteristik & $\begin{array}{l}\text { Tidak } \\
\text { berminyak, } \\
\text { lebih tipis, } \\
\text { mudah } \\
\text { menyebar } \\
\text { untuk } \\
\text { menutupi } \\
\text { area yang } \\
\text { luas }\end{array}$ & $\begin{array}{l}\text { Estetika. Terbuat dari } \\
\text { lemak yang lebih berat }\end{array}$ & $\begin{array}{l}\text { Aplikasi berikut terlihat } \\
\text { berminyak, mengkilap } \\
\text { Membentuk lapisan } \\
\text { pelindung kulit, terutama } \\
\text { berguna di lingkungan } \\
\text { dengan kelembaban } \\
\text { rendah }(<60 \%)\end{array}$ & $\begin{array}{l}\text { Produk yang halus, tidak } \\
\text { berminyak, tidak } \\
\text { komedogenik, mudah diserap }\end{array}$ \\
\hline Kegunaan & $\begin{array}{l}\text { Pelembab } \\
\text { yang dapat } \\
\text { digunakan } \\
\text { setiap hari }\end{array}$ & $\begin{array}{l}\text { Pelembab waktu malam } \\
\text { hari untuk tangan wajah, } \\
\text { dan bagian tubuh yang } \\
\text { tidak berbulu } \\
\text { Untuk digunakan saat } \\
\text { tidak diperlukan efek } \\
\text { oklusif }\end{array}$ & $\begin{array}{l}\text { Sangat menguntungkan } \\
\text { ketika tingkat oklusif } \\
\text { tinggi }\end{array}$ & $\begin{array}{l}\text { Untuk digunakan di daerah } \\
\text { intertriginosa, mudah diserap, } \\
\text { penerimaan tinggi untuk } \\
\text { wajah, non comedogenik }\end{array}$ \\
\hline
\end{tabular}




\section{Aplikasi Pelembab}

Waktu dan metode yang tepat untuk aplikasi pelembab dapat memberikan manfaat yang optimal. Seperti penggunaan humektan dan matriks hidrofilik, yang berfungsi menyerap air dari lingkungan atau menyerap air dari lapisan bawah. Penggunaan pelembab yang bersifat humektan lebih cocok digunakan saat beraktivitas diluar. Pelembab yang bersifat oklusif umumnya digunakan pada kulit yang lembab, seperti dipakai setelah mandi. ${ }^{18}$ Saat menggunakan pelembab yang telah digosokan pada telapak tangan, saat diaplikasikan, dioles dengan ringan sepanjang arah folikel rambut. Hal tersebut mencegah folikulitis minyak pada lapisan kulit. ${ }^{17}$

Distribusi pelembab bergantung pada eksipien yang digunakan. Aplikasi salep lebih merata dibandingkan dengan dengan produk yang memililiki formulasi dengan sifat viskositas yang rendah dan bahan yang mudah menguap. Transfer aktif bahan-bahan pada permuukaan kulit lebih mudah dalam pengaplikasian krim dan salep daripada Iosion dan tingtur. ${ }^{32}$ Setelah aplikasi, bahan biasanya tetap berada pada permukaan, diserap ke dalam kulit, dimetabolisme atau menghilang dari tubuh oleh karena adanya penguapan, mengelupas atau karena adanya kontak dengan bahan lain. Setelah 8 jam, biasanya hanya $50 \%$ pelembab yang tersisa pada permukaan kulit. Semua itu, tergantung pada tingkat kekeringan, keparahan, dan frekuensi pengaplikasian yang disarankan antara 1 sampai 3 kali sehari. ${ }^{17}$

\section{Dampak Buruk Penggunaan Pelembab}

Dibandingkan dengan pemberian resep dokter untuk obat topikal lainnya, pelembab jarang dikaitkan dengan bahaya kesehatan, bahkan ketika digunakan pada area permukaan tubuh yang luas dan dalam periode waktu yang lama. Berbagai ketidaknyamanan yang terkait dengan pelembab sering ditemui karena zat apapun dapat menyebabkan reaksi pada area kulit yang sensitif pada sebagian individu. Terjadinya iritasi kulit, yaitu karena adanya reaksi sensorik atau sensasi subjektif dengan atau tanpa tanda atau gejala peradangan. Hal tersebut paling sering terjadi. Pada Tabel 6. menyajikan kemungkinan yang terjadi pada saat menggunakan pelembab. ${ }^{17}$

Tabel 6. Kemungkinan efek samping dari penggunaan pelembab. ${ }^{17}$

\begin{tabular}{|l|l|}
\hline \multicolumn{1}{|c|}{ Efek yang Berlawanan } & \multicolumn{1}{c|}{ Kemungkinan Penyebab } \\
\hline Reaksi iritan & $\begin{array}{l}\text { Humektan: asam laktat, urea, bahan pengawet, } \\
\text { seperti asam benzoat dan asam sorbat. }\end{array}$ \\
& $\begin{array}{l}\text { Protein dalam lemak nabati, urea, asam hidroksil, } \\
\text { propilen glikol, pelarut-pelarut. } \\
\text { Lanolin, propilen glikol, vitamin E, pengawet, } \\
\text { wewangian, tabir surya, dan bahan herbal. }\end{array}$ \\
\hline Dermatitis & Petrolatum, minyak mineral \\
\hline Folikulitis oklusif & Wewangian, asam hidroksil, pengawet, tabir surya. \\
\hline Fotosensitifitas dan fotomelanosis & Minyak oklusif yang digunakan dalam fase W/O \\
\hline Kosmetika untuk jerawat & Asam sorbat, wewangian, dan balsam peru \\
\hline Kontak urtikaria & Propilen glikol \\
\hline Keracunan pada pasien luka bakar & Asam salisilat
\end{tabular}




\section{Pelembab dari Bahan Alam}

Formulasi kosmetik dari bahan alam telah banyak dikembangkan karena telah terbukti memberikan efek yang lebih baik, aman, dan manjur. Sifat dari bahan-bahan tersebut dapat sebagai humektan, oklusif, dan emolien yang konsisten sebagai pelembab. ${ }^{33}$ Memformulasikan kosmetik menggunakan bahan baku alami memang sulit dan memiliki tantangan tersendiri karena harus memperoleh efek fungsional yang sama dengan bahan sintetis. Bahan alam yang telah digunakan dalam formulasi pelembab disajikan dalam Tabel 7.

Tabel 7. Daftar bahan alam yang digunakan sebagai pelembab. ${ }^{34}$

\begin{tabular}{|c|c|c|}
\hline Herbal & Konstituen Kimia & Fungsi \\
\hline $\begin{array}{l}\text { Aloe barbadensis } \\
\text { (ekstrak daun) }\end{array}$ & $\begin{array}{l}\text { Barbaloin, aloe-emodin, } \\
\text { aloesin, amino acid, enzim, } \\
\text { vitamin }\end{array}$ & $\begin{array}{l}\text { Agen pelembab dan memberikan } \\
\text { efek elastisitas }\end{array}$ \\
\hline $\begin{array}{l}\text { Cucumis sativus (Jus } \\
\text { buah) }\end{array}$ & Silica, vitamin $C$, folic acid & Agen pelembab dan pengencang \\
\hline $\begin{array}{l}\text { Trigonella foenum } \\
\text { Graecum (Ekstrak bifi) }\end{array}$ & $\begin{array}{l}\text { Carbohydrates, lipids, } \\
\text { flavonoids, free }\end{array}$ & Agen pelembut \\
\hline $\begin{array}{l}\text { Triticum sativum } \\
\text { (minyak) }\end{array}$ & Vitamin E, carbohydrate & Vitamin dan oklusif \\
\hline Cocos nucifera (minyak) & Lauric oils & Agen pelembut \\
\hline $\begin{array}{l}\text { Prunus amygdalus } \\
\text { (minyak) }\end{array}$ & $\begin{array}{l}\text { Amandin, folic acid, alpha } \\
\text { tocopherol, dan zinc }\end{array}$ & Agen pelembab dan pengencang \\
\hline Oleum olivae (minyak) & & $\begin{array}{l}\text { Mencegah terjadinya } \\
\text { pengeringan }\end{array}$ \\
\hline
\end{tabular}

\section{Kesimpulan}

Pelembab dapat menjadi salah satu solusi untuk mengatasi kondisi kulit kering karena telah terbukti dapat meningkatkan hidrasi kulit dengan dengan mekanisme dan sifat sebagai humektan yang menarik air jika dioleskan pada kulit, oklusif yang dapat memblokir secara transepidermal terjadinya kehilangan air pada stratum corneum dan membantu mempertahankan kadar air, dan emolien yang pencegah penguapan air dalam kulit. Humektan, seperti gliserin dan propilen glikol merupakan bahan yang paling sering digunakan dalam formulasi pelembab kulit. Formulasi berupa eksipien dan waktu aplikasi pelembab juga turut berperan dalam pencapaian hasil yang optimal. Berdasarkan kajian di atas produk pelembab berpotensi untuk dikembangkan ditinjau dari peminatan dan kebutuhan konsumen yang menggunakan pelembab terus meningkat.

\section{Ucapan Terima Kasih}

Penulis menyampaikan ucapan terima kasih kepada Ibu Dr. rer. nat. Anis Yohana Chaerunisaa, Apt. selaku pembimbing Dermatology and Skin Care Product yang telah memberikan bimbingannya selama penulisan artikel review ini. 


\section{Daftar Pustaka}

1. Wang Y, Li J, Shang Y, Zeng X. Study on the development of wax emulsion with liquid crystal structure and its moisturizing and frictional interactions with skin. Colloids Surfaces B $\quad$ Biointerfaces. 2018;171:335-342. doi:10.1016/j.colsurfb.2018.07.039

2. Derler S, Gerhardt LC. Tribology of skin: Review and analysis of experimental results for the friction coefficient of human skin. Tribol Lett. 2012;45(1):1-27. doi:10.1007/s11249-011-9854-y

3. Wolff K, La G, Si K. Fitzpatrick 's Dermatology in Gener- al Medicine . Seventh Edition. Two. 2009;17(2):149-150.

4. Draelos ZD. An evaluation of prescription device moisturizers. J Cosmet Dermatol. 2009;8(1):40-43. doi:10.1111/j.1473-2165.2009.00422.x

5. Byun $\mathrm{HJ}$, Cho $\mathrm{KH}$, Eun $\mathrm{HC}$, et al. Lipid ingredients in moisturizers can modulate skin responses to UV in barrier-disrupted human skin in vivo. J Dermatol Sci. 2012;65(2):110-117. doi:10.1016/j.jdermsci.2011.12.005

6. Lodén M. The clinical benefit of moisturizers. J Eur Acad Dermatology Venereol. 2005;19(6):672-688. doi:10.1111/j.1468-3083.2005.01326.x

7. Linde YW. "Dry" skin in atopic dermatitis. I. A clinical study. Acta Derm Venereol. 1989;69(4):311-314

8. Rawlings A V. Ethnic skin types: Are there differences in skin structure and function? Int $J$ Cosmet Sci. 2006;28(2):79-93. doi:10.1111/j.14672494.2006.00302.x

9. Riley PA. Melanogenesis and melanoma. Pigment Cell Res. 2003;16(5):548-552. doi:10.1034/j.1600-0749.2003.00069.x

10. Taylor SC. Skin of color: Biology, structure, function, and implications for dermatologic disease. J Am Acad Dermatol. 2002;46(2 III):41-62. doi:10.1067/mjd.2002.120790

11. Wan DC, Wong VW, Longaker MT, Yang GP, Wei FC. Moisturizing different racial skin types. J Clin Aesthet Dermatol. 2014;7(6):25-32. doi:10.5005/jp/books/12966_14

12. Partogi D. Kulit kering. Dep IImu Kesehat Kulit Dan Kelamin FKUSU. 2008:1-12.

13. Hill S, Edwards C. A comparison of the effects of bath additives on the barrier function of skin in normal volunteer subjects. J Dermatolog Treat. 2002;13(1):1518. doi:10.1080/09546630252775199

14. Crowther JM, Sieg A, Blenkiron $P$, et al. Measuring the effects of topical moisturizers on changes in stratum corneum thickness, water gradients and hydration in vivo. $\mathrm{Br} J$ Dermatol. 2008;159(3):567-577. doi:10.1111/j.13652133.2008.08703.x

15. Udompataikul M. New innovation of moisturizers containing non-steroidal antiinflammatory agents for atopic dermatitis. World J Dermatologyy. 2015;4(2):108. doi:10.5314/wjd.v4.i2.108

16. Cosmetic Toiletry and Fragrance Association. International Cosmetic Ingredient Dictionary and Handbook, Volume 4.; 2006. 
17. Purnamawati S, Indrastuti N, Danarti R, Saefudin T. The role of moisturizers in addressing various kinds of dermatitis: A review. Clin Med Res. 2017;15(3-4):7587. doi:10.3121/cmr.2017.1363

18. Lodén M. Effect of moisturizers on epidermal barrier function. Clin Dermatol. 2012;30(3):286-296. doi:10.1016/j.clindermatol.2011.08.015

19. Nolan K, Marmur E. Moisturizers: Reality and the skin benefits. Dermatol Ther. 2012;25(3):229-233. doi:10.1111/j.1529-8019.2012.01504.x

20. Draelos ZD. Active agents in common skin care products. Plast Reconstr Surg. 2010;125(2):719-724. doi:10.1097/PRS.0b013e3181c83192

21. Zirwas MJ, Stechschulte SA. Moisturizer allergy: diagnosis and management. $J$ Clin Aesthet Dermatol. 2008;1(4):38-44.

22. Savary G, Grisel M, Picard C. Impact of emollients on the spreading properties of cosmetic products: A combined sensory and instrumental characterization. Colloids Surfaces B Biointerfaces. 2013;102:371-378. doi:10.1016/j.colsurfb.2012.07.028

23. Kim SK, Karadeniz F. Biological Importance and Applications of Squalene and Squalane. Vol 65. 1st ed. Elsevier Inc.; 2012. doi:10.1016/B978-0-12-4160033.00014-7

24. Wei A, Shibamoto T. Antioxidant activities of essential oil mixtures toward skin lipid squalene oxidized by UV irradiation. Cutan Ocul Toxicol. 2007;26(3):227-233. doi:10.1080/15569520701224501

25. Kato S, Aoshima H, Saitoh Y, Miwa N. Biological safety of lipoFullerene composed of squalane and fullerene-C60 upon mutagenesis, photocytotoxicity, and permeability into the human skin tissue. Basic Clin Pharmacol Toxicol. 2009;104(6):483-487. doi:10.1111/j.1742-7843.2009.00396.x

26. Simpson E, Böhling A, Bielfeldt S, Bosc C, Kerrouche N. Improvement of skin barrier function in atopic dermatitis patients with a new moisturizer containing a ceramide precursor. J Dermatolog Treat. 2013;24(2):122-125. doi:10.3109/09546634.2012.713461

27. BOLLIGER A, GROSS R. Water soluble compounds (non-keratins) associated with the skin flakes of the human scalp. Aust J Exp Biol Med Sci. 1956;34(3):219224. doi:10.1038/icb.1956.26

28. Harding, Watkinson, Rawlings, Scott. Dry skin, moisturization and corneodesmolysis. Int $J$ Cosmet Sci. 2000;22(1):21-52. doi:10.1046/j.14672494.2000.00001.x

29. Kraft J, Lynde C. Moisturizers: What they are and a practical approach to product selection. Skin Therapy Lett. 2005;10:1-8.

30. Madison KC. Barrier Function of the Skin. J Invest Dermatol. 2003;121(2):231241.

31. Draelos ZD. Therapeutic moisturizers. Dermatol Clin. 2000;18(4):597-607.

32. Ivens UI, Steinkjer B, Serup J, Tetens V. Ointment is evenly spread on the skin, in contrast to creams and solutions. Br J Dermatol. 2001;145(2):264-267. doi:10.1046/j.1365-2133.2001.04344.x

33. R Awlings A V, Avid C Anestrari DA, Rian Obkowski BD. Dermatologic therapy Moisturizer technology versus clinical performance. Dermatol Ther. 2004;17:4956 . 
34. Kapoor S, Saraf S. Formulation and Evaluation of Moisturizer Containing Herbal Extracts for the Management of Dry Skin. Pharmacogn J. 2010;2(11):409-417. doi:10.1016/s0975-3575(10)80024-0 